\title{
Measuring Career Adaptability in a Sample of Italian University Students: Psychometric Properties and Relations with the Age, Gender, and STEM/No STEM Courses
}

\author{
Marina Mondo ${ }^{1}$, Barbara Barbieri ${ }^{2, * \mathbb{D}}$, Silvia De Simone ${ }^{1} \mathbb{D}$, Flavia Bonaiuto ${ }^{3}$, Luca Usai ${ }^{2}$ and $_{\text {Mirian }}$ Agus ${ }^{1}(\mathbb{D}$ \\ 1 Department of Pedagogy, Psychology, Philosophy, University of Cagliari, 09123 Cagliari, Italy; \\ mmondo@unica.it (M.M.); desimone@unica.it (S.D.S.); mirian.agus@unica.it (M.A.) \\ 2 Department of Political and Social Sciences, University of Cagliari, Viale Sant'Ignazio 78, 09123 Cagliari, Italy; \\ luca.usai@unica.it \\ 3 Faculty of Economics, Universitas Mercatorum, 00186 Roma, Italy; flavia.bonaiuto@unimercatorum.it \\ * Correspondence: barbara.barbieri@unica.it
}

Citation: Mondo, Marina, Barbara Barbieri, Silvia De Simone, Flavia Bonaiuto, Luca Usai, and Mirian Agus. 2021. Measuring Career Adaptability in a Sample of Italian University Students: Psychometric Properties and Relations with the Age, Gender, and STEM/No STEM Courses. Social Sciences 10: 372 https://doi.org/10.3390/ socsci10100372

Academic Editor: Nigel Parton

Received: 27 July 2021

Accepted: 18 September 2021

Published: 2 October 2021

Publisher's Note: MDPI stays neutral with regard to jurisdictional claims in published maps and institutional affiliations.

Copyright: (c) 2021 by the authors. Licensee MDPI, Basel, Switzerland. This article is an open access article distributed under the terms and conditions of the Creative Commons Attribution (CC BY) license (https:// creativecommons.org/licenses/by/ $4.0 /)$.

\begin{abstract}
The continuous transformation of the labor market, characterized by great instability and uncertainty, and by rapid technological changes, has strongly influenced the construction and management of career paths. Nowadays, individuals are faced with careers that are fluid and boundaryless, characterized by discontinuity and a variety of organizations to deal with. In this scenario, the ability to adapt and react to continuous changes in the labor market and in organizations is now a priority for workers. This study presents the psychometric properties of the construct of Career Ability measured through Proactive Personality and Boundaryless Mindset as proxy variables in a sample of 579 adults enrolled at the University of Cagliari (Italy), or recently graduated therein. We aim to rate the factorial structure of the items and to evaluate their multi-group invariance regarding the gender variable. Moreover, the criterion and concurrent validity were assessed. The instrument shows good psychometric characteristics; factorial structure, factorial invariance in relation to the gender variable, concurrent, and criterion validities were confirmed.
\end{abstract}

Keywords: career adaptability; proactive personality; boundaryless mindset; gender; stem/no stem courses; university students

\section{Introduction}

Economic and financial crises, and deep social changes within recent decades, have profoundly changed careers management. The concept of the working life span has certainly changed compared to the past; in fact, if it was previously possible and foreseeable to enter a few working contexts during one's career (Eby et al. 2003), today individuals are faced with careers that are fluid and boundaryless (Briscoe and Hall 2006; Sullivan and Arthur 2006), characterized by discontinuity and a variety of organizations to deal with. The ability to adapt and react to continuous changes in the labor market and in organizations is now a priority for workers (Carter 2019). Therefore, those who are in a transition phase between higher education and the working world, such as university students, must be able, right from the start, to express this ability (Hamzah et al. 2021), which involves developing the propensity to be flexible, resilient, and take control of their careers (Alisic and Wiese 2020; Jackson and Tomlinson 2020; Zacher 2015). Several studies concur that the individuals who are best able to adapt to new circumstances are also those who can find work and build successful careers (Cortellazzo et al. 2020; Holtschlag et al. 2020; Kundi et al. 2020). The concept of career adaptability was postulated by Super and Kansel (1981) and developed by Savickas (2013), who defines it as a psychosocial resource, and a combination of attitudes, skills, and behaviors that help individuals adapt to the job they have chosen, in which self-knowledge and one's personal characteristics become 
essential elements for developing this ability. Concern, control, curiosity, and confidence are the characteristics that help individuals to cope with the changes and unforeseen events that may occur in their professional career (Guan et al. 2016). According to Fugate and colleagues (Fugate et al. 2004), adaptability is defined as the ability that people have to change behavior, feelings, and thoughts with the aim of responding to the changes in the environment in which they are inserted. The individuals with this ability are able to manage ambiguity, uncertainty, are less exposed to stress, and more able to act outside predetermined boundaries ( $\mathrm{O}^{\prime} \mathrm{C}$ Connell et al. 2008). Some authors point out that proactive personality is an important component of adaptability (Cai et al. 2015; Fawehinmi and Yahya 2018; Hameed et al. 2020; Hou et al. 2014; Jiang 2017; Öncel 2014; Savickas and Porfeli 2012; Tolentino et al. 2014) together with boundaryless mindset (Chan et al. 2015; Stauffer et al. 2019).

Considering the potential importance of Career Adaptability measured through Proactive Personality and Boundaryless Mindset as proxy variables (McArdle et al. 2007), the purpose of this paper was to explore the psychometric features of the Italian version of the instrument in a sample of young adults, not yet employed and looking for professional integration, in the context of recent developments in the international labor market. Therefore, the study aimed to assess the factorial structure of the items and to evaluate their multi-group invariance regarding the gender variable (Byrne 2001, 2004, 2008, 2013). Moreover, the concurrent validity and criterion validity were assessed.

\section{Literature Review}

In recent years, studies have paid great attention to the construct of career adaptability, almost prefiguring the new scenarios triggered by the COVID-19 pandemic (Chen et al. 2020b). For students facing the transition phase, in order to enter work, learning to adapt in an ever-changing environment is recognized as one of the most important skills and one of the main factors related to job success (Rudolph et al. 2017; Spurk et al. 2013) in job search strategies (Koen et al. 2010), employability (Spurk et al. 2016) and performance (Zacher 2015). As Tolentino and colleagues (Tolentino et al. 2014), and Ginevra and colleagues (2018) suggest, adaptability allows individuals to face unexpected problems that are not easy to solve, enabling them to achieve a functional balance with the environment in which they are inserted. In a recent literature review, Chen and colleagues (Chen et al. 2020b) found that this specific field of study basically encompasses five main clusters (described in their study by the high frequency keyword grouping characteristics): boundaryless mindset, career adaptability scale, career construction, proactive personality, and life design. Despite this, the same review (Chen et al. 2020b) shows that the most important measurement scales on career adaptability have focused on different psychological dimensions (see for example: The Career Adapt Ability Scale (CAAS), by Savickas and Porfeli (2012); The Career Adapt abilities Scale-Short Form (CAAS-SF) by Maggiori et al. (2017); The Career Futures Inventory-Revised (CFI-R) Rottinghaus et al. (2012)), pointing out that researchers have developed different scales according to their own research. While the constructs of the boundaryless mindset and the proactive personality are among the most common in theoretical studies of career adaptability, none of the aforementioned scales uses them. Only one study (McArdle et al. 2007), to the best of the authors' knowledge, used proactive personality and boundaryless mindset as proxy measures for adaptability.

The aim of the aforementioned study was to empirically test the employability model of Fugate and colleagues (Fugate et al. 2004) through three separate but inter-connected psycho-social dimensions: adaptability, career identity, and human and social capital. In that study, adaptability was measured through the proactive personality and Boundaryless mindset, as operationalized by Bateman and Crant (1993), and Briscoe and colleagues (Briscoe et al. 2006). The adaptability variables (i.e., boundaryless mindset and proactive personality), seem to be those that, in this time of great environmental turbulence and important change in the contract forms between workers and organizations, more fit with a no longer traditional career concept that allows people to operate in a VUCA environment 
(Pryor et al. 2008). The ability to cope with "disordered, complex, and unwritten problems" is now considered an essential learning outcome of higher education (Nelson Laird et al. 2009). Workers need to be comfortable with ambiguity; evaluate the quality of the available data; keep a clear view of the larger image; identify options when blocked, challenged or rejected; scan media broadly and efficiently; accurately identify the central issues in a conflict; and challenge conventional methods, systems, and thinking (Feller and O'Bruba 2009; Shaffer and Zalewski 2011). Traditional career theory was a useful way to help students make career decisions by narrowing, channeling, or focusing their attention on potential career choices, often following a strategy of matching students' skills, attitudes, values, or personality traits with occupations or specific professions (Van Vianen et al. 2009). Today, however, in post-industrial economies, careers are often fragmented and protean, requiring workers to be willing as well as being able to stay within a flow of continuous growth and experimentation (Parker 2008; Van Vianen et al. 2009).

\section{Components of Career Adaptability}

\subsection{Proactive Personality}

Different studies link career adaptability to proactive personality (Cai et al. 2015; Fawehinmi and Yahya 2018; Green et al. 2019; Hameed et al. 2020; Hou et al. 2014; Jiang 2017; McArdle et al. 2007; Öncel 2014; Tolentino et al. 2014; Uy et al. 2015). The proactive personality can be defined as a stable disposition that makes individuals able to actively intervene in the environment, and more independent of situational factors and always looking for new opportunities for improvement and learning (Seibert et al. 1999; Wang and Wanberg 2017). Proactive personality finds its theoretical foundations in interactionism (Bowers 1973) and in social cognitive theory (Bandura 1986), for which there is a constant reciprocal interaction between the person, the environment, and behavior. The construct, which first appeared in a study by Bateman and Crant (Bateman and Crant 1993), was used in contrast to the concept of passive personality. People with proactive personalities are relatively independent of their surroundings; they are able to seize opportunities that present themselves and persevere in their actions until the result is achieved. Subsequently, other authors have defined individuals with proactive personalities as future-oriented, creative, self-sufficient, able to constantly improve, and have an optimistic orientation towards change, as well as being able to profitably enter the labor market (Brown et al. 2006; Campbell 2000; Fuller and Marler 2009; Greguras and Diefendorff 2010; Kim et al. 2009; Parker et al. 2006; Spitzmuller et al. 2015).

Still, other studies have linked proactive personality with a series of positive outcomes. The results showed how proactive personality affects learning ability and strengthens social capital and future orientation, self-directed career management, successful job searches, the results of the socialization process of newbies in organizations, career success, job satisfaction, well-being, and the effectiveness of the leadership process (Ashford and Black 1996; Bateman and Crant 1993; Briscoe et al. 2006; Crant 2000; de Guzman and Choi 2013; Frese et al. 2007; Ryff and Singer 2008; Seibert et al. 2001; Soresi et al. 2012; Spitzmuller et al. 2015; Valls et al. 2020; Uy et al. 2015; Zheng et al. 2020). Furthermore, being proactive supports a boundaryless career mindset (Briscoe et al. 2006; Jackson 1996; Lochab and Nath 2020; Mirvis and Hall 1996), and has a strong influence on the perception of career self-efficacy (Brown et al. 2006; Frese and Fay 2001; Kim and Park 2017). Bocciardi and colleagues (Bocciardi et al. 2017), for example, link the proactive personality to a high ability to make optimal career decisions and an overall improvement in professional life (Parker et al. 2006). Jiang (2017), Hameed, and colleagues (Hameed et al. 2020), and Öncel (2014), argue that proactive personality is able to influence the development of career adaptability in adult workers, while other authors (Cai et al. 2015; Hou et al. 2014; Tolentino et al. 2014) reach the same results in samples composed of university students who identify proactive personality as an antecedent of career adaptability. Rudolph and colleagues (Rudolph et al. 2017), analyzing 90 studies in their meta-analysis, identified proactive personality as one of the measures of adaptivity most associated with adaptability. 


\subsection{Boundaryless Mindset}

In literature, another variable associated with career adaptability and proactive personality is the boundaryless mindset (Arthur 1994; Arthur and Rousseau 1996; Li et al. 2021; Spurk et al. 2013). Individuals with a boundaryless mindset conceive of their career as barrier-free and prefer organizations without traditional borders; they pursue career opportunities and relationships beyond a single employer and favor situations in which it is possible to physically move between jobs, professions, and different geographic areas (Sullivan and Arthur 2006). Hence, it is preferable to a career vision characterized by the lack of physical and psychological boundaries (Cheramie et al. 2007), and appears to be composed of two dimensions: physical mobility, more focused on the changeability of jobs and employers' work (Gubler et al. 2014; Sullivan and Baruch 2009), and the psychological one, more oriented to maintaining relationships beyond organizational boundaries that do not necessarily involve physical mobility (Briscoe and Finkelstein 2009; Rodrigues and Guest 2010; Verbruggen 2012). Among the factors that contribute most to the boundaryless mindset are proactive personality, protean career, employability, and self-efficacy in job search (Brown et al. 2006; Fugate et al. 2004; Wiernik and Kostal 2019). Zhao and colleagues (Zhao et al. 2016) found that the boundaryless mindset is related to work performance abroad through the mediation of proactive resources, while Kundi and colleagues (Kundi et al. 2020) have shown that the boundaryless mindset is a predictor of career success. Subsequently, Li and colleagues ( $\mathrm{Li}$ et al. 2021), carrying out a meta-analysis on contemporary career attitudes, verified the existence of a positive correlation between the boundaryless mindset and intrinsic and extrinsic career success, job satisfaction, and proactive personality. In their study, these authors also assert that, if on the one hand workers with a boundaryless mindset are highly appreciated by organizations, on the other hand those who are oriented towards larger networks may not be well regarded by companies, as they are more inclined to turnover. This generates the need to deepen the studies on contemporary career attitudes not only from the point of view of how beneficial these attitudes are for the individual career (Hall et al. 2018), but also how convenient or harmful they can be for organizations. Another criticism comes from Pringle and Mallon (2003) who underline that boundaryless career theory does not sufficiently take into account aspects such as social structures, the national context, gender, and ethnicity.

\section{Proactivity Personality, Boundaryless Mindset and Demographic Characteristics}

Several studies have investigated proactive personality and the boundaryless mindset from a gender and age perspective. These two constructs are strongly related to adaptability (Green et al. 2019; Hameed et al. 2020; Li et al. 2021; McArdle et al. 2007; Spurk et al. 2013), so it is important to understand whether being more independent from situational factors (Wang and Wanberg 2017) and having a career vision characterized by the lack of physical and psychological boundaries (Arthur and Rousseau 1996) can account for the current gap between men and women, or between young and older employees in terms of adaptability and profitable entry into the labor market.

\subsection{Proactive Personality with Gender and Age}

Spitzmuller and colleagues (Spitzmuller et al. 2015), in their meta-analytic review, showed no significant gender differences in the proactive personality, although the literature suggests that women have a lower power perception than men (Keltner et al. 2003), and ts it would make them less inclined to engage in proactive behaviors, such as challenging the status quo and overcoming obstacles to making meaningful change for women (Bateman and Crant 1993). Likewise, no significant difference by gender was observed in the studies of Travis and Freeman (2017) on a sample of university students, of Özkurt and Berkan (2018) concerning high school students, of Zhang and colleagues (Zhang et al. 2020) on a sample of graduating university students, who were moving from university to work, and of Hua and colleagues (Hua et al. 2020) in the analysis of an international students sample. At the same time, De Pater and colleagues (De Pater et al. 2009) highlighted how 
women have a lower proactive personality than male colleagues in research that considered a sample of interns.

McArdle and colleagues (McArdle et al. 2007) and Zhang and colleagues (Zhang et al. 2021) found no age or gender differences in terms of proactive personality in their respective research on Australian unemployment, on high-tech company employees, as well as Wang and colleagues (Wang and Wanberg 2017) in a sample of employee-supervisor dyads, and Thomas and colleagues (Thomas et al. 2010) in their comparative meta-analysis. Regarding age, some research has shown that older and younger workers do not differ in their levels of proactivity (Bertolino et al. 2011; Erdogan and Bauer 2005; Harvey et al. 2006; Seibert et al. 2001), while other studies (Truxillo et al. 2012) suggest that older workers would be perceived as lower than younger workers in terms of their proactive personality.

\subsection{Boundaryless Mindset with Gender, Age and STEM/No STEM Degrees}

Guan and colleagues (Guan et al. 2019), in their literature review, highlight how numerous individual moderators have been taken into consideration regarding the boundaryless mindset and, among them, age and gender, which would create further difficulties and barriers to career promotion (Forrier et al. 2009). Besides, different studies had already shown that one of the limits of the boundaryless mindset theory was just to not give due importance to such measures (Eby et al. 2003; Enache et al. 2011; Pringle and Mallon 2003).

Some studies have pointed out that, in general, women seem to have a higher psychological mobility, while men would have higher physical mobility and would be more motivated by economic factors, while women seem more oriented towards relational careers and more driven by the variety in work (Inceoglu et al. 2009; Mainiero and Sullivan 2005; Sullivan and Arthur 2006; Warr 2008). Segers and colleagues (Segers et al. 2008), investigating a large sample of European workers, not only confirmed the previous statements but found a significant difference in terms of age with respect to physical mobility, which sees the latter decrease with increasing age. Conversely, the Bednarska-Wnuk study (Bednarska-Wnuk 2020) found no statistically significant differences between men and women regarding boundaryless mindset in a sample of workers.

Even the Kostal and Wiernik studies (Kostal and Wiernik 2017), and Abid and colleagues (Abid et al. 2021), point in this direction, defining demographic differences in reference to boundaryless mindset negligible. For Briscoe and colleagues (Briscoe et al. 2006), there is no difference in gender, but a slight and significant positive relationship between age and boundaryless mindset was demonstrated in a sample made up of undergraduate business students, graduate students, and managers. In another study conducted on a sample of European Information Technology professionals (Gubler et al. 2014), younger respondents indicated a significantly higher preference for mobility than older ones, and the rejection of career opportunities were positively correlated to age.

Finally, different authors have taken into consideration the differences between STEM (Science, Technology, Engineering, and Maths) and NON STEM degree courses in reference to the development of soft skills, which can help facilitate the transition from university to the labor market (Dika and D'Amico 2016; Whalen and Shelley 2010; Wilson 2010; Xu 2012). Some research highlights that in STEM courses, employability skills are often underestimated and undertrained in educational paths (Rayner and Papakonstantinou 2016). What has been highlighted in these studies is that non-STEM disciplines programs, such as business studies, involve developing employability skills, while STEM programs, while successfully preparing STEM graduates with the academic knowledge necessary for the workplace, do not invest in soft skills development, and these students often lack interpersonal and transferable skills, practical experience, general workplace experience, or required business knowledge (Prinsley and Baranyai 2015).

According to several studies, training that implements not only specialized technical knowledge but also soft skills, such as adaptability and proactivity, would support job placement (McGunagle and Zizka 2018, 2020; Hartmann and Jahren 2015; Rayner and Papakonstantinou 2015) and would make future workers better able to find creative 
solutions to demands from workplace (Dyke-Ford and Teare 2006; Hartmann and Jahren 2015; Maxwell et al. 2010). Comparisons between different degree courses could help to differentiate the guidance programs in universities and to broaden knowledge relating to the factors facilitating placement.

\section{Materials and Methods}

\subsection{Participants}

The assessment was conducted on 579 adults enrolled at the University of Cagliari (Italy), or recently graduated therein, and $53.9 \%$ were women. The average age of the participants was 26 years (ranging from 19 to 60 years; standard deviation $=6.51$ ). The $43 \%$ of participants attended STEM degrees. The average mark of their exams was $23.4(\mathrm{sd}=6.8)$.

Participants were divided randomly in two groups in order to carry out two studies: a first study with explorative approach $(n=250)$, and a second with a confirmatory approach ( $n=329$; the second sub-sample had to be more numerous than the first, in order to have an adequate size to apply the confirmatory analyses required for the assessment of factorial invariance).

The sampling was nonprobabilistic. Participants, after receiving an invitation via their institutional university email, volunteered to participate in an online survey by selfcompleting a questionnaire administered in November 2019. Participation in the study was on a voluntary basis, and the data collected were anonymous and confidential. The participants were informed of details concerning the aim of the data collection, and they gave their consent to the data treatment. The protocol was administrated through the Google Drive forms, using the lists of students enrolled in the CareerDay of the University of Cagliari. All ethical guidelines were applied, following the procedures defined by the institutional research committee, by the American Psychological Association (APA), by the Italian Association of Psychology (AIP), and by the 1964 Helsinki declaration (with their and subsequent amendments). The descriptive statistics for all variables and subsamples are showed in Table 1.

Table 1. Descriptive statistics.

\begin{tabular}{lcc}
\hline \multicolumn{1}{c}{ Variable } & Study $\mathbf{1}(\boldsymbol{n}=\mathbf{2 5 0 )}$ & Study 2 $(\boldsymbol{n = 3 2 9 )}$ \\
\hline Percentage of women & $53.20 \%$ & $52.58 \%$ \\
\hline Age-Mean $(\mathrm{sd})$ & $26.260(6.659)$ & $26.049(6.756)$ \\
\hline Average of mark-Mean (sd) & $23.680(6.511)$ & $23.138(7.277)$ \\
\hline Type of degree- STEM (\%) & $42.6 \%$ & $43.5 \%$ \\
\hline Dimensions Inquired & & $5.204(0.820)$ \\
\hline Proactive Personality-Mean (sd) & $5.194(0.715)$ & $3.918(0.551)$ \\
\hline Boundaryless mindset-Mean (sd) & $3.879(0.561)$ &
\end{tabular}

\subsection{Instruments and Procedure}

The items of the original scales were translated by the application of translation/backtranslation process; these items were previously evaluated by a group of experts and a group of students in order to evaluate their comprehensibility. The final Italian version of the instrument is showed in the Appendix A.

The Proactive Personality (PP) scale was developed by Bateman and Crant (1993), and in this study we used the version of Seibert and colleagues (Seibert et al. 1999), validated in Italy by Trifiletti and colleagues (Trifiletti et al. 2009). This scale has been translated and adapted in many countries, always showing good psychometric properties [e.g., French version by Carrein (2011); Spanish version by Valor-Segura et al. (2020); Chinese version by Shang and Gan (2009); Korean version by Kim and Park (2017); Indian version by Lochab and Nath (2020); Turkish validation by Öncel (2014)]. The scale was characterized by 10 items and rated on a Likert scale from one (strongly disagree) to seven (strongly 
agree). One element was, for example: "If I see something I don not like, I will fix it." The alpha reliability in our sample was 0.799. The Boundaryless Mindset Scale (BLM) was developed by Briscoe and colleagues (Briscoe et al. 2006) and validated in Italy by Lo Presti and colleagues (Lo Presti et al. 2011) as one of the factors of the Boundaryless Career Attitude Scale (Briscoe et al. 2006). This tool has been validated in many countries [for example, in Spain by Lochab and Nath (2020); in France by Stauffer et al. (2019); in Turkey by Çakmak-Otluoğlu and Bolat (2020); in the Philippines by Bernardo and Salanga (2019)]. The scale is defined by 8 items, rated on a 5-step Likert scale (from one-strongly agree-to five-strongly disagree). This is an example of a scale item: "I am looking for work assignments that allow me to learn something new." The alpha reliability obtained in our sample was 0.851 .

\subsection{Data Analysis}

Statistical data analyses were applied following a multi-stage approach. Specifically, participants were separated in two comparable subsamples.

In the initial phase, a Principal Component Analysis was applied in the first subsample.

Then, a Confirmatory Factor Analysis was applied for males and females separately; the model hypothesized two correlated factors.

Formerly, the factorial invariance was assessed through the Multigroup Confirmatory Factor Analysis (Byrne 2008; Hirschfeld and Von Brachel 2014), which allows one to simultaneously evaluate the data from different groups. This aim is accomplished by constraining some parameters to assume the equal values in the samples. By means of this technique, measurement invariance can be measured at different levels. A configural invariance specifies that the number of latent constructs and the patterns of factor loadings are comparable in the two groups (configural invariance). A weak invariance suggests that the earlier conditions are fulfilled and that we have metric invariance (i.e., the magnitude of factor loading is similar in two groups) (metric invariance). A strong invariance happens when the earlier requirements are observed, and scalar invariance is reached (i.e., the items' intercepts are analogous across the groups) (scalar invariance). A strict invariance is reached once, over and above the previous conditions, residual variances are similar across the groups (strict invariance) (Hirschfeld and Von Brachel 2014). For each formerly cited model, the parameters were forced to be equal across the groups; the fit of each model was associated with the strong measurement invariance. So as to choose on the invariance of measurement, variations in the fit indices were detected; specifically the $\triangle C F I$ was considered $(\triangle C F I<0.01$ is the recommended cut-off point to determine if a further constrained model indicates a substantial reduction in model fit regarding a fewer constrained model) (Chen 2007).

The Confirmatory Factor Analyses (estimator ML) were applied by the software R 4.0.2 (R Core Team 2021); precisely, the packages lavaan, semTools, and semPlot were used (Epskamp 2017; Jorgensen et al. 2016; Rosseel 2017). Furthermore, concurrent validity was evaluated by the computation of Pearson's r coefficients. Specifically, we referred to concurrent validity as an assessment of the consistency of the measure with an immediately observable behaviour or event (e.g., in our case, classically, with the average mark of examinations carried out at the university) (Chiorri 2020; Cronbach and Meehl 1955; Guion and Cranny 1982).

Finally, the criterion validity was assessed by the application of a Multivariate Analysis of Covariance, using the age as covariate, the degree, and the gender as between factors (Chiorri 2020).

\section{Results}

\subsection{Study 1}

The data collected were assessed in order to evaluate the normality of distributions, and computing the indices of skewness (ranging from -1.248 to -0.089 ) and kurtosis (ranging from -0.813 to 0.861 ). Furthermore, a priori, we determine the minimum sample 
size required to achieve an acceptable level of statistical power for the factor structure under evaluation (Thompson 2004; Cohen 2013). Moreover, we verify that the data met the requirements for the application of the PCA (Kaiser-Meyer-Olkin index $=0.838$ ) and the CFA.

We applied the Principal Component Analysis on the items, with Promax rotation (Table 2). In this analysis were observed two principal components (PC1-Scale PP, Eigenvalue $=5.421 ;$ Proportion of variance explained $=0.301 ; \mathrm{PC} 2-$ Scale BLM, Eigenvalue $=$ 2.269-Proportion of variance explained $=0.126$ ); these principal components showed a correlation of 0.429 . The internal consistency (Cronbach's Alpha) of the two dimensions is satisfactory (F1 $\alpha=0.799 ; \mathrm{F} 2 \alpha=0.851)$.

Table 2. PCA, Component Loadings.

\begin{tabular}{|c|c|c|c|c|}
\hline Items & & PC1 & PC2 & Uniqueness \\
\hline I am constantly on the lookout for new ways to improve my life. & PP1 & & 0.353 & 0.782 \\
\hline Wherever I have been, I have been a powerful force for constructive change. & PP2 & & 0.581 & 0.622 \\
\hline Nothing is more exciting than seeing my ideas turn into reality. & PP3 & & 0.452 & 0.806 \\
\hline If I see something I don't like, I fix it. & PP4 & & 0.687 & 0.569 \\
\hline No matter what the odds, if I believe in something I will make it happen. & PP5 & & 0.752 & 0.496 \\
\hline I love being a champion for my ideas, even against others' opposition. & PP6 & & 0.474 & 0.817 \\
\hline I excel at identifying opportunities. & PP7 & & 0.673 & 0.534 \\
\hline I am always looking for better ways to do things. & PP8 & & 0.570 & 0.598 \\
\hline If I believe in an idea, no obstacle will prevent me from making it happen. & PP9 & & 0.744 & 0.499 \\
\hline I can spot a good opportunity long before others can. & PP10 & & 0.692 & 0.468 \\
\hline I seek job assignments that allow me to learn something new. & BLM1 & 0.526 & & 0.678 \\
\hline I would enjoy working on projects with people across many organizations. & BLM2 & 0.741 & & 0.431 \\
\hline I enjoy job assignments that require me to work outside of the organization. & BLM3 & 0.717 & & 0.503 \\
\hline I like tasks at work that require me to work beyond my own department. & BLM4 & 0.732 & & 0.485 \\
\hline I enjoy working with people outside of my organization. & BLM5 & 0.829 & & 0.368 \\
\hline $\begin{array}{l}\text { I enjoy jobs that require me to interact with people in many different } \\
\text { organizations. }\end{array}$ & BLM6 & 0.784 & & 0.430 \\
\hline $\begin{array}{l}\text { I have sought opportunities in the past that allow me to work outside the } \\
\text { organization. }\end{array}$ & BLM7 & 0.627 & & 0.615 \\
\hline I am energized in new experiences and situations. & BLM8 & 0.515 & & 0.608 \\
\hline
\end{tabular}

Note. Applied rotation method is Promax; PC = Principal component.

\subsection{Study 2}

In the second subsample of participants, the confirmatory factor analyses (CFAs-in which the parameters were estimated by maximum likelihood method) were carried out. These analyses were applied three times in relation to the total subsample of the study, and furthermore (regarding the assessment of the factorial invariance in relation to the gender variable), separately for males and females.

We inspected the data fit regarding to two correlated factors. With the intention of evaluating the models, several classical indices were computed: the ratio of Chi Square and the degrees of freedom, that it is demarcated as acceptable if it is under three (SchermellehEngel et al. 2003; Wheaton et al. 1977); the Comparative Fit Index-CFI (Bentler 1990), that is considered acceptable if higher than 0.90 (Byrne 2001); the indices Root Mean Square Error of Approximation (RMSEA) (Steiger 1990) and Standardized Root Mean Square Residual (SRMR), that were considered adequate if lesser than 0.08 (Hu and Bentler 1999).

The CFAs presented good fit indices (Table 3), supporting the factor structure of the instrument.

Then, we carried out multigroup confirmatory factor analysis. This approach consents the measurement invariance of the scale to be measured across groups of participants (males and females) who are likely to have the similar levels of the latent constructs (Byrne 2008). Table 4 shows the fit indices of the nested CFA carried out, from configural to strict invariance models. 
Table 3. Results of the application of CFAs in the study 2.

\begin{tabular}{ccccccccccc}
\hline & Factor Loadings & df & $\begin{array}{c}\text { Chi } \\
\text { Square }\end{array}$ & $\begin{array}{c}\text { Chi } \\
\text { Square/df }\end{array}$ & $\boldsymbol{p}$ & RMSEA & $\begin{array}{c}\text { RMSEA } \\
\text { [90\% CI] }\end{array}$ & SRMR CFI & GFI \\
\hline Total sample & From 0.33 to 1.01 & 134 & 254.154 & 1.896 & $<0.0001$ & 0.053 & $0.043-0.063$ & 0.074 & 0.967 & 0.962 \\
\hline Males & From 0.39 to 0.98 & 134 & 168.922 & 1.260 & 0.022 & 0.042 & $0.017-0.060$ & 0.088 & 0.978 & 0.946 \\
\hline Female & From 0.40 to 0.82 & 134 & 135.425 & 1.010 & 0.449 & 0.008 & $0.000-0.039$ & 0.073 & 0.999 & 0.964 \\
\hline
\end{tabular}

Note: $\mathrm{df}=$ degrees of freedom; RMSEA $(90 \% \mathrm{CI})=$ Root Mean Square Error of Approximation with Confidence Interval; SRMR = Standardized Root Mean Square Residual; CFI = Comparative Fit Index; GFI = Goodness of Fit Index.

Table 4. Measurement invariance models regarding the two groups (males/females).

\begin{tabular}{cccccccccc}
\hline & df & Chi Square & $p$ & Chi Square $\boldsymbol{\Delta}$ & Df $\boldsymbol{\Delta}$ & CFI & RMSEA & CFI $\Delta$ & RMSEA $\Delta$ \\
\hline $\begin{array}{c}\text { Model 1: } \\
\text { configural }\end{array}$ & 268 & 304.347 & 0.063 & & & 0.990 & 0.029 & 0.003 \\
\hline $\begin{array}{c}\text { Model 2: } \\
\text { metric }\end{array}$ & 284 & 330.684 & 0.029 & 26.337 & 16 & 0.987 & 0.032 & 0.003 \\
\hline $\begin{array}{c}\text { Model 3: } \\
\text { scalar }\end{array}$ & 300 & 340.417 & 0.054 & 9.733 & 16 & 0.989 & 0.029 & 0.002 \\
\hline $\begin{array}{c}\text { Model 4: } \\
\text { strict }\end{array}$ & 318 & 355.659 & 0.072 & 15.242 & 18 & 0.990 & 0.028 & 0.001 & 0.001 \\
\hline
\end{tabular}

Note: $\mathrm{df}=$ degrees of freedom; RMSEA $(90 \% \mathrm{CI})=$ Root Mean Square Error of Approximation with Confidence Interval; CFI = Comparative Fit Index; $\Delta=$ differences in fit indices between the unconstrained baseline model and the stronger constrained models.

The fits are good (Cheung and Rensvold 2002); the differences in fit indices amongst the unrestricted baseline model and the robust constrained models highlight for our data a strict factorial invariance, confirming the validity and usefulness of this assessment instrument, and furthermore the invariance regarding the gender variable. Specifically, this evidence of invariance implies that the males and females conceive of the constructs investigated in the same way.

Moreover, linear correlations (Pearson's r) (Table 5) were computed between the assessed variables, the age, and the average grade achieved on university exams. These coefficients highlighted specifically that BLM have a significant positive correlation with age and PP; the average grade in exams show a negative significant correlation with PP.

Table 5. Pearson's r correlations.

\begin{tabular}{ccccc}
\hline & & Age & $\begin{array}{c}\text { Average Grade on } \\
\text { University Exams }\end{array}$ & PP \\
\hline \multirow{2}{*}{ average grade on university exams } & $\mathrm{r}$ & 0.006 & 1 & \\
\hline & $p$ & 0.889 & & 1 \\
\hline \multirow{2}{*}{ PP } & $\mathrm{r}$ & 0.025 & $-0.100^{*}$ & 0.016 \\
& $p$ & 0.550 & -0.044 & $0.386^{* *}$ \\
\hline \multirow{2}{*}{ BLM } & $\mathrm{r}$ & $0.125^{* *}$ & 0.299 & 0.001 \\
\hline
\end{tabular}

Note $={ }^{* *} p<0.01 ;{ }^{*} p<0.05$ (2 tailed); PP = Proactive Personality; BLM = Boundaryless mindset; $\mathrm{r}=$ Pearson's $\mathrm{r}$ correlation.

To evaluate potential differences regarding the dimensions PP and BLM in relation to the socio-demographic variables, a Multivariate analysis of covariance (MANOVA) were carried out, having as covariate the age, as between factors gender and type of degree (STEM-NO STEM).

The analysis underlined a multivariate effect of the covariate age (Wilk's Lambda $(2,565)=0.981 ; p=0.005$; partial Eta Squared $=0.019)$, a multivariate main effect of the 
variable degree (Wilk's Lambda ${ }_{(2,565)}=0.972 ; p=0.0001$; partial Eta Squared $\left.=0.028\right)$, and a multivariate main effect of gender (Wilk's Lambda ${ }_{(2,565)}=0.982 ; p=0.006$; partial Eta Squared $=0.018)$. The interaction between degree ${ }^{*}$ gender is not significant (Wilk's Lambda $\left._{(2,565)}=0.998 ; p=0.519\right)$.

At the univariate level, the effect of the covariate age is significant for the BLM $(\mathrm{F}=2.702 ; p=0.003$; partial Eta Squared =0.016). Always at the univariate level, the main effect of the variable degree is significant for the scale $\operatorname{PP}(\mathrm{F}(1,566)=10.443 ; p=0.001$; partial Eta Squared =0.018). Specifically, the students in the NO STEM degrees have higher scores than STEM students in this scale $($ STEM mean $=5.075$, standard deviation $=0.747$; NO STEM mean = 5.269; standard deviation $=0.789$ ).

Furthermore, at the univariate level, the variable gender show a significant effect regarding the BLM $(\mathrm{F}(1,566)=4.786 ; p=0.029$; partial Eta Squared $=0.008)$. Indeed, in this scale, females have higher scores (mean $=3.940$; standard deviation $=0.525$ ) than males $($ mean $=3.850 ;$ standard deviation $=0.572)$.

\section{Discussion and Conclusions}

This study explored the career adaptability construct, defined as the ability that people have to change behavior, feelings, and thoughts with the aim of responding to the changes in the environment in which they are inserted (Fugate et al. 2004). According to McArdle and colleagues (McArdle et al. 2007), career adaptability can be measured through proxy the two variables: Proactive Personality (Cai et al. 2015; Fawehinmi and Yahya 2018; Hameed et al. 2020; Hou et al. 2014; Jiang 2017; Öncel 2014; Savickas and Porfeli 2012; Tolentino et al. 2014), and Boundaryless Mindset (Chan et al. 2015; Stauffer et al. 2019).

Validating a scale capable of assessing career adaptability in the Italian context would allow us to explore the ability of individuals to adapt to different contexts and to the continuous changes they encounter during their life span (Carter 2019).

For these reasons, the purpose of this article was to explore the psychometric properties of the Italian version of the Career Adaptability using the Proactive Personality and the Boundaryless Mindset as proxy measures (McArdle et al. 2007).

A multi-stage approach was used for the data analysis and the participants were divided into two sub-samples. The first subsample was used for the analysis of the principal components with Promax rotation; as hypothesized, the presence of two main components, PP and BLM, with a satisfactory internal consistency emerged.

The second subsample was used to perform a Confirmatory Factor Analysis for males and females separately. This approach allows measuring the measurement invariance of the scale between groups of participants (male and female), who might show similar levels of latent constructs (Byrne 2008); specifically, the results confirm a strict factorial invariance. The scale highlighted good validity and usefulness, furthermore, the invariance with respect to the detected gender variable confirms that males and females conceive the constructs investigated in the same way. Subsequently a Multivariate analysis of covariance (MANOVA) was carried out in order to assess the existence of potential differences in the scores of PP and BLM. Assuming age as a covariate variable, the gender and type of degree (STEM-NO STEM) were taken into consideration. The analysis highlighted a multivariate main effect of the "degree course type" variable and a multivariate main effect of the gender. The main effect of the "degree course type" variable is significant for the PP scale, in which it is observed that NO STEM degree students are more proactive than STEM students.

This results is in line with previous researches, which highlight that employability skills continue to be a crucial gap in STEM paths (Harvey 2005; Maxwell and Armellini 2019; Maxwell et al. 2010). In academia, there probably still persists the idea that in some paths, the hard knowledge of a specialized technical type is the only one necessary to enter the working world. At the same time, there is a misperception that these skills can or should be learned on the job; if this were true, they would be called occupational skills or employee skills, not occupational skills (McGunagle and Zizka 2020). 
Instead, other studies have highlighted the importance of good levels of proactivity in STEM degree students. For example, Major and colleagues (Major et al. 2012) found that students with a proactive personality demonstrated a greater commitment than students with a low proactive personality in STEM study paths; according to other authors, individuals with proactive personalities are well suited to modern career paths, such as those within STEM degrees (Fuller and Marler 2009) as they are more likely to see challenges as learning opportunities (Elliot and Harackiewicz 1996) characteristics that can be useful in the rapidly evolving technology fields.

Regarding gender, the results on career adaptability are conflicting and often considered inconclusive (Patton and Lokan 2001; Patton et al. 2004). In studies on student samples, females showed higher levels of career adaptability than males (Çizel 2018; Hartung et al. 2005), and more specifically regarding personal and emotional adaptability (Chen et al. 2020a). On the contrary, other studies, always on student samples, did not show gender differences (Cheung and Jin 2016; Ghosh and Fouad 2017; Hirschi et al. 2015; Koen et al. 2012; Rottinghaus et al. 2005; Tien et al. 2014; Zacher 2014). In the present work, the gender variable shows a significant effect with respect to BLM. Females appear to have higher levels of BLM and this finding contrasts with previous research that defines gender differences in relation to the construct as negligible (Abid et al. 2021; Bednarska-Wnuk 2020; Briscoe et al. 2006; Kostal and Wiernik 2017), although in line with others studies that attribute greater psychological mobility and motivation to the female gender (Inceoglu et al. 2009; Mainiero and Sullivan 2005; Segers et al. 2008; Sullivan and Arthur 2006; Warr 2008). These latter findings suggest the opportunity to provide ad hoc counseling programs for males and females students in order to overcome the difficulties linked in the first case to a low propensity to mobility, and in the second case to greater attention to relationships and to the change of intra-organizational role.

In conclusion, instrument shows good psychometric characteristics; factorial structure, factorial invariance in relation to the gender variable, concurrent and criterion validities were confirmed.

\section{Practical Implication}

Proactive individuals who perceive their career as unfettered by predetermined boundaries are more likely to be employable. University students are especially required to express this ability in the transition phase to the working world (Alisic and Wiese 2020; Hamzah et al. 2021; Jackson and Tomlinson 2020), considering that the success of this transition is linked to adaptability (Cortellazzo et al. 2020; Holtschlag et al. 2020; Kundi et al. 2020). An important aspect to consider is that many programs aimed at supporting unemployed job seekers have not proved effective (Nielsen Arendt et al. 2020; Card et al. 2018). It would be advisable to intervene before facing the transition phase to the labor market, especially during the university path, in order to foster an attitude to engage in adaptive behaviors before career transitions can serve as preparation and favor the success and quality of the work (Koen et al. 2010; Hirschi 2010; McGunagle 2016; McGunagle and Zizka 2018).

The scale validated in the present research would allow intercepting individuals who do not have good levels of career adaptability and who may have difficulty in entering the job market profitably. By having available data on the presence of a low proactive personality and low levels of boundaryless mindset, it would be possible to build guidance interventions capable of preventing critical issues and increasing the probability of success. Previous studies suggest that there are several psychosocial areas on which it could be possible to intervene to improve personal adaptability: for example self-efficacy (Blackmore et al. 2021; Dillahunt and Hsiao 2021; Guan et al. 2013), self-esteem (Amarnani et al. 2018; Cai et al. 2015); team work skills (de Guzman and Choi 2013; Ebenehi et al. 2016; Fawehinmi and Yahya 2018), learning goal orientation and, past and future temporal focus (Tolentino et al. 2014; Zacher 2015), resilience (Buyukgoze-Kavas 2016) problem solving and decision making (Kozlowski et al. 2001; Coetzee et al. 2015). 
These interventions could be carried out both at the individual level with targeted counseling sessions, both at the group level with training moments, and at the organizational level through the implementation of professional orientation policies. Equally important are the accompanying paths to internships and post-graduate internships as a fundamental moment of encounter between the knowledge acquired in the study courses, life skills, and the necessary skills to achieve future optimal performance.

\section{Limitations of the Study}

Some limitations of this study must be considered. Primarily, the sampling was non probabilistic; it would be useful for the ongoing research to apply a stratified probabilistic sampling, to balance some relevant socio-demographic variables (as the geographical area). Additional, given the cross-sectional nature of this research, it is difficult to precisely assess the direction for the associations observed in our sample; it might be interesting to organize longitudinal studies to provide further suggestions about these relationships. Also, the assessment of further psychological dimensions might be useful to define specificities of Proactive Personality and Boundaryless mindset.

Author Contributions: All authors developed the research project. L.U. and B.B. collected the data. M.M., B.B., F.B., S.D.S., worked on the literature. M.M. and B.B. developed theoretical background. M.A. performed methods and data analysis. M.M., B.B., M.A., F.B., S.D.S. worked on the conclusions and practical implications. M.M., B.B. and M.A. have reviewed the manuscript. All authors have read and agreed to the published version of the manuscript.

Funding: This research received no external funding.

Institutional Review Board Statement: Ethical review and approval were not required for the study on human participants, in accordance with the local legislation and institutional requirements.

Informed Consent Statement: The participants provided their written informed consentto participate in this study. Informed consent was obtained from allsubjects involved in the study.

Data Availability Statement: The datasets generated for this study are available on request to the corresponding author.

Conflicts of Interest: The authors declare no conflict of interest.

Research Ethic: Ethical review and approval were not required for the study on human participants, in accordance with the local legislation and institutional requirements. The participants provided their written informed consent to participate in this study. Informed consent was obtained from all subjects involved in the study.

\section{Appendix A}

Italian version of the instrument

Per favore, leggi le seguenti affermazioni e indica il tuo grado di accordo secondo la seguente scala:

\begin{tabular}{lllllll}
\hline 1 & 2 & 3 & 4 & 5 & 6 & 7 \\
$\begin{array}{l}\text { Totalmente in } \\
\text { disaccordo }\end{array}$ & In disaccordo & $\begin{array}{l}\text { Leggermente in } \\
\text { disaccordo }\end{array}$ & $\begin{array}{l}\text { Né in accordo, né in } \\
\text { disaccordo }\end{array}$ & $\begin{array}{l}\text { Leggermente } \\
\text { d'accordo }\end{array}$ & $\begin{array}{l}\text { Totalmente in } \\
\text { accordo }\end{array}$ \\
\hline
\end{tabular}




\begin{tabular}{|c|c|c|c|c|c|c|c|}
\hline Sono costantemente alla ricerca di nuovi modi per migliorare la mia vita. & 1 & 2 & 3 & 4 & 5 & 6 & 7 \\
\hline $\begin{array}{l}\text { In ogni contesto in cui sono stato, ho esercitato una forte influenza per un } \\
\text { cambiamento costruttivo. }\end{array}$ & 1 & 2 & 3 & 4 & 5 & 6 & 7 \\
\hline Niente è più emozionante che vedere le mie idee trasformarsi in realtà. & 1 & 2 & 3 & 4 & 5 & 6 & 7 \\
\hline Se c'è qualcosa che non mi va bene, posso risolvere il problema. & 1 & 2 & 3 & 4 & 5 & 6 & 7 \\
\hline Non importa quali siano le probabilità, se credo in qualcosa, la farò accadere. & 1 & 2 & 3 & 4 & 5 & 6 & 7 \\
\hline Mi piace che le mie idee prevalgano, anche contro l'opposizione degli altri. & 1 & 2 & 3 & 4 & 5 & 6 & 7 \\
\hline Ho talento nell'individuare opportunità. & 1 & 2 & 3 & 4 & 5 & 6 & 7 \\
\hline Sono sempre alla ricerca di modi migliori per fare le cose. & 1 & 2 & 3 & 4 & 5 & 6 & 7 \\
\hline Se credo in un'idea, nessun ostacolo mi impedirà di farla accadere. & 1 & 2 & 3 & 4 & 5 & 6 & 7 \\
\hline Posso individuare una buona occasione molto prima che lo facciano gli altri & 1 & 2 & 3 & 4 & 5 & 6 & 7 \\
\hline
\end{tabular}

Per favore, leggi le seguenti affermazioni e indica il tuo grado di accordo secondo la seguente scala:

\begin{tabular}{|c|c|c|c|c|c|c|c|}
\hline 1 & 2 & \multirow{2}{*}{\multicolumn{2}{|c|}{$\begin{array}{l}3 \\
\text { Né in accordo, né in } \\
\text { disaccordo }\end{array}$}} & \multirow{2}{*}{\multicolumn{2}{|c|}{$\begin{array}{l}4 \\
D^{\prime} \text { accordo }\end{array}$}} & \multicolumn{2}{|l|}{5} \\
\hline $\begin{array}{l}\text { Totalmente in } \\
\text { disaccordo }\end{array}$ & In disaccordo & & & & & \multicolumn{2}{|c|}{ Totalmente in accordo } \\
\hline \multicolumn{3}{|c|}{$\begin{array}{l}\text { Cerco incarichi di lavoro che mi permettano di imparare qualcosa } \\
\text { di nuovo }\end{array}$} & 1 & 2 & 3 & 4 & 5 \\
\hline \multicolumn{3}{|c|}{$\begin{array}{l}\text { Mi piacerebbe lavorare su progetti con persone di diverse } \\
\text { organizzazioni }\end{array}$} & 1 & 2 & 3 & 4 & 5 \\
\hline \multicolumn{3}{|c|}{$\begin{array}{l}\text { Mi piacciono gli incarichi di lavoro che mi richiedono di lavorare } \\
\text { al di fuori dell'organizzazione }\end{array}$} & 1 & 2 & 3 & 4 & 5 \\
\hline \multicolumn{3}{|c|}{$\begin{array}{l}\text { Mi piacciono quei compiti lavorativi che mi richiedono di } \\
\text { lavorare oltre il mio luogo di lavoro. }\end{array}$} & 1 & 2 & 3 & 4 & 5 \\
\hline \multicolumn{3}{|c|}{$\begin{array}{l}\text { Mi piace lavorare con persone al di fuori della mia } \\
\text { organizzazione. }\end{array}$} & 1 & 2 & 3 & 4 & 5 \\
\hline \multicolumn{3}{|c|}{$\begin{array}{l}\text { Mi piacciono lavori che mi obbligano a interagire con persone di } \\
\text { differenti organizzazioni. }\end{array}$} & 1 & 2 & 3 & 4 & 5 \\
\hline \multicolumn{3}{|c|}{$\begin{array}{l}\text { In passato ho cercato opportunità che mi permettessero di } \\
\text { lavorare al di fuori del contesto organizzativo in cui stavo. }\end{array}$} & 1 & 2 & 3 & 4 & 5 \\
\hline \multicolumn{3}{|c|}{ Nuove esperienze e nuove situazioni mi attivano. } & 1 & 2 & 3 & 4 & 5 \\
\hline
\end{tabular}

\section{References}

Abid, Gulam, Bindu Arya, Amara Arshad, Saira Ahmed, and Saira Farooqi. 2021. Positive personality traits and self-leadership in sustainable organizations: Mediating influence of thriving and moderating role of proactive personality. Sustainable Production and Consumption 25: 299-311. [CrossRef]

Alisic, Aida, and Bettina S. Wiese. 2020. Keeping an insecure career under control: The longitudinal interplay of career insecurity, self-management, and self-efficacy. Journal of Vocational Behavior 120: 103431. [CrossRef]

Amarnani, Rajiv K., Patrick Raymund James M. Garcia, Simon Lloyd D. Restubog, Prashant Bordia, and Sarbari Bordia. 2018. Do you think I'm worth it? The self-verifying role of parental engagement in career adaptability and career persistence among STEM students. Journal of Career Assessment 26: 77-94. [CrossRef]

Arthur, Michael B. 1994. The boundaryless career: A new perspective for organizational inquiry. Journal of Organizational Behavior 15: 295-306. [CrossRef]

Arthur, Michael B., and Denise M. Rousseau. 1996. The Boundaryless Career: A New Employment Principle for a New Organizational Era. Oxford: Oxford University Press, pp. 370-82.

Ashford, Susan J., and J. Stewart Black. 1996. Proactivity during organizational entry: The role of desire for control. Journal of Applied Psychology 81: 199-214. [CrossRef] 
Bandura, Albert. 1986. Social Foundations of Thought and Action. Englewood Cliffs: Prentice Hall.

Bateman, Thomas S., and J. Michael Crant. 1993. The proactive component of organizational behavior: A measure and correlates. Journal of Organizational Behavior 14: 103-18. [CrossRef]

Bednarska-Wnuk, Izabela. 2020. Boundaryless Career: Research Perspectives. Zeszyty Naukowe Uniwersytetu Ekonomicznego w Krakowie 2: 7-24. [CrossRef]

Bentler, Peter M. 1990. Comparative fit indexes in structural models. Psychological Bulletin 107: 238-46. [CrossRef] [PubMed]

Bernardo, Allan B. I., and Maria Guadalupe C. Salanga. 2019. Validating the protean and boundaryless career attitudes scales with Filipino young adults. Cogent Psychology 6: 1-15. [CrossRef]

Bertolino, Marilena, Donald M. Truxillo, and Franco Fraccaroli. 2011. Age as moderator of the relationship of proactive personality with training motivation, perceived career development from training, and training behavioral intentions. Journal of Organizational Behavior 32: 248-63. [CrossRef]

Blackmore, Conner, Julian Vitali, Louise Ainscough, Tracey Langfield, and Kay Colthorpe. 2021. A Review of Self-Regulated Learning and Self-Efficacy: The Key to Tertiary Transition in Science, Technology, Engineering and Mathematics (STEM). International Journal of Higher Education 10: 169-77. [CrossRef]

Bocciardi, Federica, Andrea Caputo, Chiara Fregonese, Viviana Langher, and Riccardo Sartori. 2017. Career adaptability as a strategic competence for career development. European Journal of Training and Development 41: 67-82. [CrossRef]

Bowers, Kenneth S. 1973. Situationism in psychology: An analysis and a critique. Psychological Review 80: 307-36. [CrossRef] [PubMed]

Briscoe, Jon P., and Douglas T. Hall. 2006. The interplay of boundaryless and protean careers: Combinations and implications. Journal of Vocational Behavior 69: 4-18. [CrossRef]

Briscoe, Jon P., and Lisa M. Finkelstein. 2009. The "new career" and organizational commitment. Career Development International 14: 242-60. [CrossRef]

Briscoe, Jon P., Douglas T. Hall, and Rachel L. Frautschy DeMuth. 2006. Protean and boundaryless careers: An empirical exploration. Journal of Vocational Behavior 69: 30-47. [CrossRef]

Brown, Douglas J., Richard T. Cober, Kevin Kane, Paul E. Levy, and Jarrett Shalhoop. 2006. Proactive personality and the successful job search: A field investigation with college graduates. Journal of Applied Psychology 91: 717-26. [CrossRef]

Buyukgoze-Kavas, Aysenur. 2016. Predicting career adaptability from positive psychological traits. The Career Development Quarterly 64: 114-25. [CrossRef]

Byrne, Barbara M. 2001. Structural Equation Modeling with AMOS, EQS, and LISREL: Comparative Approaches to Testing for the Factorial Validity of a Measuring Instrument. International Journal of Testing 1: 55-86. [CrossRef]

Byrne, Barbara M. 2004. Testing for Multigroup Invariance Using AMOS Graphics: A Road Less Traveled. Structural Equation Modeling: A Multidisciplinary Journal 11: 272-300. [CrossRef]

Byrne, Barbara M. 2008. Testing for multigroup equivalence of a measuring instrument: A walk through the process. Psicothema 20: 872-82.

Byrne, Barbara M. 2013. Structural Equation Modeling with Mplus: Basic Concepts, Applications, and Programming. Londra: Routledge.

Cai, Zijun, Yanjun Guan, Hongyan Li, Wei Shi, Kun Guo, Yi Liu, Qinglin Li, Xue Han, Peng Jiang, Zheng Fang, and et al. 2015. Self-esteem and proactive personality as predictors of future work self and career adaptability: An examination of mediating and moderating processes. Journal of Vocational Behavior 86: 86-94. [CrossRef]

Çakmak-Otluoğlu, Övgü K., and Bilge Acar Bolat. 2020. Short forms of protean and boundaryless career attitudes scales in the Turkish context: Validation and psychometric evaluation. International Journal for Educational and Vocational Guidance 21: 263-83. [CrossRef]

Campbell, Donald J. 2000. The proactive employee: Managing workplace initiative. Academy of Management Perspectives 14: 52-66. [CrossRef]

Card, David, Jochen Kluve, and Andrea Weber. 2018. What works? A meta-analysis of recent active labor market program evaluations. Journal of the European Economic Association 16: 894-931. [CrossRef]

Carrein, Cindy. 2011. L'entrée en Consultation D'accompagnement en Orientation Scolaire et Professionnelle: Analyse des Déterminants, Modélisation et Aide au Changement [Meeting with a Career Counselor: Determinants Analysis, Modeling and Help to Change]. Unpublished Doctoral dissertation, Université de Rouen, Mont-Saint-Aignan, France.

Carter, Angela J. 2019. Young People, Employment and Work Psychology: Interventions and Solutions. Londra: Routledge.

Chan, Kim Yin, Marylin A. Uy, Moon-Ho R. Ho, Yoko Loo Sam, Oleksandr S. Chernyshenko, and Kang-Yang T. Yu. 2015. Comparing two career adaptability measures for career construction theory: Relations with boundaryless mindset and protean career attitudes. Journal of Vocational Behavior 87: 22-31. [CrossRef]

Chen, Fang F. 2007. Sensitivity of Goodness of Fit Indexes to Lack of Measurement Invariance. Structural Equation Modeling: A Multidisciplinary Journal 14: 464-504. [CrossRef]

Chen, Huaruo, Ling Ling, Yonghui Ma, Ya Wen, Xiyuan Gao, and Xueying Gu. 2020a. Suggestions for chinese university freshmen based on adaptability analysis and sustainable development education. Sustainability 12: 1371. [CrossRef]

Chen, Huaruo, Tingting Fang, Fan Liu, Liman Pang, Ya Wen, Shi Chen, and Xueying Gu. 2020b. Career adaptability research: A literature review with scientific knowledge mapping in web of science. International Journal of Environmental Research and Public Health 17: 5986. [CrossRef] 
Cheramie, Robin A., Michael C. Sturman, and Kate Walsh. 2007. Executive career management: Switching organizations and the boundaryless career. Journal of Vocational Behavior 71: 359-74. [CrossRef]

Cheung, Gordon W., and Roger B. Rensvold. 2002. Evaluating Goodness-of-Fit Indexes for Testing Measurement Invariance. Structural Equation Modeling: A Multidisciplinary Journal 9: 233-55. [CrossRef]

Cheung, Raysen, and Qiuping Jin. 2016. Impact of a career exploration course on career decision making, adaptability, and relational support in Hong Kong. Journal of Career Assessment 24: 481-96. [CrossRef]

Chiorri, Carlo. 2020. Fondamenti Di Psicometria. Milano: Mac Graw Hill.

Çizel, Rabia. 2018. Gender and emotional intelligence as predictors of tourism faculty students' career adaptability. Advances in Hospitality and Tourism Research (AHTR) 6: 188-204. [CrossRef]

Coetzee, Melinde, Nadia Ferreira, and Ingrid L. Potgieter. 2015. Assessing employability capacities and career adaptability in a sample of human resource professionals. SA Journal of Human Resource Management 13: 1-9. [CrossRef]

Cohen, Jacob. 2013. Statistical Power Analysis for the Behavioral Sciences. Cambridge: Academic Press.

Cortellazzo, Laura, Sara Bonesso, Fabrizio Gerli, and Joan M. Batista-Foguet. 2020. Protean career orientation: Behavioral antecedents and employability outcomes. Journal of Vocational Behavior 116: 103343. [CrossRef]

Crant, J. Michael. 2000. Proactive behavior in organizations. Journal of Management 26: 435-62. [CrossRef]

Cronbach, Lee J., and Paul E. Meehl. 1955. Construct validity in psychological tests. Psychological Bulletin 52: 281-302. [CrossRef] [PubMed]

de Guzman, Allan B., and Kyoung Ok Choi. 2013. The relations of employability skills to career adaptability among technical school students. Journal of Vocational Behavior 82: 199-207. [CrossRef]

De Pater, Irene E., Annelies E. M. Van Vianen, Agneta H. Fischer, and Wendy P. Van Ginkel. 2009. Challenging experiences: Gender differences in task choice. Journal of Managerial Psychology 24: 4-28. [CrossRef]

Dika, Sandra L., and Mark D'Amico. 2016. Early experiences and integration in the persistence of first-generation college students in STEM and non-STEM majors. Journal of Research in Science Teaching 53: 368-83. [CrossRef]

Dillahunt, Tawanna R., and Joey Chiao-Yin Hsiao. 2021. SkillsIdentifier: A Tool to Promote Career Identity and Self-efficacy Among Underrepresented Job Seekers. Paper presented at 54th Hawaii International Conference on System Sciences January 5, Hawaii; pp. 1-10.

Dyke-Ford, Julie, and Scott W. Teare. 2006. The right answer is communication when capstone engineering courses drive the questions. Journal of STEM Education 7: 5-12.

Ebenehi, Amos Shaibu, Abdullah Mat Rashid, and Ab Rahim Bakar. 2016. Predictors of career adaptability skill among higher education students in Nigeria. International Journal for Research in Vocational Education and Training (IJRVET) 3: 212-29. [CrossRef]

Eby, Lillian T., Marcus Butts, and Angie Lockwood. 2003. Predictors of success in the era of the boundaryless career. Journal of Organizational Behavior 24: 689-708. [CrossRef]

Elliot, Andrew J., and Judith M. Harackiewicz. 1996. Approach and avoidance achievement goals and intrinsic motivation: A mediational analysis. Journal of Personality and Social Psychology 70: 461-75. [CrossRef]

Enache, Mihaela, Jose M. Sallan, Pep Simo, and Vicenc Fernandez. 2011. Examining the impact of protean and boundaryless career attitudes upon subjective career success. Journal of Management and Organization 17: 459-73. [CrossRef]

Epskamp, Sasha. 2017. Package 'semPlot'. Available online: https://cran.r-project.org/web/packages/semPlot/semPlot.pdf (accessed on 20 August 2019).

Erdogan, Berrin, and Talya N. Bauer. 2005. Enhancing career benefits of employee proactive personality: The role of fit with jobs and organizations. Personnel Psychology 58: 859-91. [CrossRef]

Fawehinmi, Olawole Olanre, and Khulida Kirana Yahya. 2018. Investigating the linkage between proactive personality and social support on career adaptability amidst undergraduate students. Journal of Business and Social Review in Emerging Economies 4: 81-92. [CrossRef]

Feller, Rich, and Brian O'Bruba. 2009. The evolving workplace: Integrating academy and career advising. In The Handbook of Career Advising. Edited by Kenneth F. Hughey, Dorothy B. Nelson, Joanne K. Damminger and Betsy McCalla-Wriggins. San Francisco: Jossey-Bass.

Forrier, Anneleen, Luc Sels, and Dave Stynen. 2009. Career mobility at the intersection between agent and structure: A conceptual model. Journal of Occupational and Organizational Psychology 82: 739-59. [CrossRef]

Frese, Michael, and Doris Fay. 2001. Personal initiative (PI): An active performance concept for work in the 21st century. In Research in Organizational Behavior. Edited by Barry M. Staw and Robbie M. Sutton. Amsterdam: Elsevier Science, vol. 23 , pp. $133-87$.

Frese, Michael, Harry Garst, and Doris Fay. 2007. Making things happen: Reciprocal relationships between work characteristics and personal initiative in a four-wave longitudinal structural equation model. Journal of Applied Psychology 92: 1084-102. [CrossRef] [PubMed]

Fugate, Mel, Angelo J. Kinicki, and Blake E. Ashforth. 2004. Employability: A psycho-social construct, its dimensions, and applications. Journal of Vocational Behavior 65: 14-38. [CrossRef]

Fuller, Bryan, and Laura Marler. 2009. Change driven by nature: A meta-analytic review of the proactive personality literature. Journal of Vocational Behavior 75: 329-45. [CrossRef]

Ghosh, Arpita, and Nadya A. Fouad. 2017. Career adaptability and social support among graduating college seniors. The Career Development Quarterly 65: 278-83. [CrossRef] 
Green, Zane Asher, Uzma Noor, and Mohammad Nawaz Hashemi. 2019. Furthering Proactivity and Career Adaptability among University Students: Test of Intervention. Journal of Career Assessment 28: 402-24. [CrossRef]

Greguras, Gary J., and James M. Diefendorff. 2010. Why does proactive personality predict employee life satisfaction and work behaviors? A field investigation of the mediating role of the self-concordance model. Personnel Psychology 63: 539-60. [CrossRef]

Guan, Pianpian, Alessandra Capezio, Simon L. D. Restubog, Shari Read, Jennifer Ann L. Lajom, and Min Li. 2016. The role of traditionality in the relationships among parental support, career decision-making self-efficacy and career adaptability. Journal of Vocational Behavior 94: 114-23. [CrossRef]

Guan, Yanju, Hong Deng, Sun Jiaqing, Wang Yanan, Cai Zijun, Ye Lihui, Fu Ruchunyi, Wang Yang, Zhang Sh, and Li Yuhui. 2013. Career adaptability, job search self-efficacy and outcomes: A three-wave investigation among Chinese university graduates. Journal of Vocational Behavior 83: 561-70. [CrossRef]

Guan, Yanjun, Michael B. Arthur, Svetlana N. Khapova, Rosalie J. Hall, and Robert G. Lord. 2019. Career boundarylessness and career success: A review, integration and guide to future research. Journal of Vocational Behavior 110: 390-402. [CrossRef]

Gubler, Martin, John Arnold, and Crispin Coombs. 2014. Organizational boundaries and beyond. Career Development International 19: 641-67. [CrossRef]

Guion, Robert M., and C. J. Cranny. 1982. A note on concurrent and predictive validity designs: A critical reanalysis. Journal of Applied Psychology 67: 239-44. [CrossRef]

Hall, Douglas T., Jeffrey Yip, and Kathryn Doiron. 2018. Protean careers at work: Self-direction and values orientation in psychological success. Annual Review of Organizational Psychology and Organizational Behavior 5: 129-56. [CrossRef]

Hameed, Irfan, Sanam Brohi, and Atif Shahab. 2020. Impact of Proactive Personality on Career Adaptability and Intentions for Expatriation. Canadian Journal of Career Development 19: 4-14.

Hamzah, Siti Raba'ah, Khoo Kai Le, and Siti Nur Syuhada Musa. 2021. The mediating role of career decision self-efficacy on the relationship of career emotional intelligence and self-esteem with career adaptability among university students. International Journal of Adolescence and Youth 26: 83-93. [CrossRef]

Hartmann, Beth L., and Charles T. Jahren. 2015. Leadership: Industry needs for entry-level engineering positions. Journal of STEM Education 16: 13-19. [CrossRef]

Hartung, Paul J., Erik J. Porfeli, and Fred W. Vondracek. 2005. Child vocational development: A review and reconsideration. Journal of Vocational Behavior 66: 385-419. [CrossRef]

Harvey, Lee. 2005. Embedding and integrating employability. New Directions for Institutional Research 128: 13-28. [CrossRef]

Harvey, Steve, Caroline Blouin, and Dave Stout. 2006. Proactive personality as a moderator of outcomes for young workers experiencing conflict at work. Personality and Individual Differences 40: 1063-74. [CrossRef]

Hirschfeld, Gerrit, and Ruth Von Brachel. 2014. Multiple-Group confirmatory factor analysis in R-A tutorial in measurement invariance with continuous and ordinal. Practical Assessment, Research and Evaluation 19: 1-11.

Hirschi, Andreas, Anne Herrmann, and Anita C. Keller. 2015. Career adaptivity, adaptability, and adapting: A conceptual and empirical investigation. Journal of Vocational Behavior 87: 1-10. [CrossRef]

Hirschi, Andreas. 2010. The role of chance events in the school-to-work transition: The influence of demographic, personality and career development variables. Journal of Vocational Behavior 77: 39-49. [CrossRef]

Holtschlag, Claudia, Aline D. Masuda, B. Sebastian Reiche, and Carlos Morales. 2020. Why do millennials stay in their jobs? The roles of protean career orientation, goal progress and organizational career management. Journal of Vocational Behavior 118: 103366. [CrossRef]

Hou, Chunna, Lin Wu, and Zhijun Liu. 2014. Effect of proactive personality and decision-making self-efficacy on career adaptability among Chinese graduates. Social Behavior and Personality: An International Journal 42: 903-12. [CrossRef]

$\mathrm{Hu}$, Li-tze, and Peter M. Bentler. 1999. Cutoff criteria for fit indexes in covariance structure analysis: Conventional criteria versus new alternatives. Structural Equation Modeling: A Multidisciplinary Journal 6: 1-55. [CrossRef]

Hua, Jing, Guilin Zhang, Charles Coco, Teng Zhao, and Ning Hou. 2020. Proactive Personality and Cross-Cultural Adjustment: The Mediating Role of Adjustment Self-Efficacy. Journal of International Students 10: 817-35. [CrossRef]

Inceoglu, Ilke, Jesse Segers, Dave Bartram, and Daniël Vloeberghs. 2009. Age differences in work motivation in a sample from five northern European countries. Zeitschrift für Personalpsychologie 8: 59-70. [CrossRef]

Jackson, Charles. 1996. Managing and developing a boundaryless career: Lessons from dance and drama. European Journal of Work and Organizational Psychology 5: 617-28. [CrossRef]

Jackson, Denise, and Michael Tomlinson. 2020. Investigating the relationship between career planning, proactivity and employability perceptions among higher education students in uncertain labour market conditions. Higher Education 80: 435-55. [CrossRef]

Jiang, Zhou. 2017. Proactive personality and career adaptability: The role of thriving at work. Journal of Vocational Behavior 98: 85-97. [CrossRef]

Jorgensen, Terrence D., Sunthud Pornprasertmanit, Patrick Miller, Alexander M. Schoemann, and Yves Rosseel. 2016. Package 'semTools'. Available online: https:/ / cran.r-project.org/web/packages/semTools/semTools.pdf (accessed on 7 July 2021).

Keltner, Dacher, Deborah H. Gruenfeld, and Cameron Anderson. 2003. Power, approach, and inhibition. Psychological Review 110: 265-84. [CrossRef]

Kim, Hyang Sook, and In-Jo Park. 2017. Influence of proactive personality on career self-efficacy. Journal of Employment Counseling 54: 168-82. [CrossRef] 
Kim, Tae-Yeol, Alice H. Y. Hon, and J. Michael Crant. 2009. Proactive personality, employee creativity, and newcomer outcomes: A longitudinal study. Journal of Business and Psychology 24: 93-103. [CrossRef]

Koen, Jessie, Ute-Christine Klehe, Annelies E. M. Van Vianen, Jelena Zikic, and Aukje Nauta. 2010. Job-search strategies and reemployment quality: The impact of career adaptability. Journal of Vocational Behavior 77: 126-39. [CrossRef]

Koen, Jessie, Ute-Christine Klehe, and Annelies E. M. Van Vianen. 2012. Training career adaptability to facilitate a successful school-to-work transition. Journal of Vocational Behavior 81: 395-408. [CrossRef]

Kostal, Jack W., and Brenton M. Wiernik. 2017. A meta-analytic investigation of demographic differences in protean, boundaryless, and proactive career orientations. Career Development International 22: 520-45. [CrossRef]

Kozlowski, Steve W. J., Rebecca J. Toney, R. J. Morell, E. Mullins, Daniel A. Weissbein, Kenneth G. Brown, and Bradford S. Bell. 2001. Developing adaptability: A theory for the design of integrated-embedded training systems. In Advances in Human Performance and Cognitive Engineering Research. Edited by Salas Eduardo. Amsterdam: JAI/Elsevier Science, pp. 59-123.

Kundi, Yasir Mansoor, Sandrine Hollet-Haudebert, and Jonathan Peterson. 2020. Linking Protean and Boundaryless Career Attitudes to Subjective Career Success: A Serial Mediation Model. Journal of Career Assessment 29: 263-82. [CrossRef]

Li, Christina S., Daniel D. Goering, Michael R. Montanye, and Rong Su. 2021. Understanding the career and job outcomes of contemporary career attitudes within the context of career environments: An integrative meta-analysis. Journal of Organizational Behavior, 1-24. [CrossRef]

Lo Presti, Alessandro, Marcello Nonnis, and Jon P. Briscoe. 2011. The protean and boundaryless career in Italy: Game on? In Boundaryless Careers and Occupational Well-Being. Edited by Cortini Michela, Tanucci Giancarlo and Morin Estelle. London: Palgrave Macmillan, pp. 7-16.

Lochab, Anshu, and Vishnu Nath. 2020. Proactive personality, goal orientation and meta-skills as predictors of protean and boundaryless career attitudes. South Asian Journal of Business Studies 9: 130-43. [CrossRef]

Maggiori, Christian, Jérôme Rossier, and Mark L. Savickas. 2017. Career adapt-abilities scale-short form (CAAS-SF) construction and validation. Journal of Career Assessment 25: 312-25. [CrossRef]

Mainiero, Lisa A., and Sherry E. Sullivan. 2005. Kaleidoscope careers: An alternate explanation for the "opt-out" revolution. Academy of Management Perspectives 19: 106-23. [CrossRef]

Major, Debra A., Jonathan M. Holland, and Kurt L. Oborn. 2012. The influence of proactive personality and coping on commitment to STEM majors. The Career Development Quarterly 60: 16-24. [CrossRef]

Maxwell, Gillian, Bernadette Scott, Dorothy Macfarlane, and Elisabeth Williamson. 2010. Employers as stakeholders in postgraduate employability skills development. International Journal of Management Education 8: 1-11. [CrossRef]

Maxwell, Rachel, and Alejandro Armellini. 2019. Identity, employability and entrepreneurship: The ChANGE framework of graduate attributes. Higher Education, Skills and Work-Based Learning 9: 76-91. [CrossRef]

McArdle, Sarah, Lea Waters, Jon P. Briscoe, and Douglas T. Hall. 2007. Employability during unemployment: Adaptability, career identity and human and social capital. Journal of Vocational Behavior 71: 247-64. [CrossRef]

McGunagle, Doreen, and Laura Zizka. 2018. Meeting real world demands of the global economy: An employer's perspective. Journal of Aviation/Aerospace Education and Research 27: 59-76. [CrossRef]

McGunagle, Doreen, and Laura Zizka. 2020. Employability skills for 21st-century STEM students: The employers' perspective. Higher Education, Skills and Work-Based Learning 10: 591-606. [CrossRef]

McGunagle, Doreen. 2016. Meeting real work demands of the global economy. I-manager's Journal on Management 10: 36-41.

Mirvis, Philip H., and Douglas T. Hall. 1996. Psychological success and the boundaryless career. In The Boundaryless Career: A New Employment Principle for a New Organizational Era. Edited by Michael B. Arthur and Denise M. Rousseau. New York: Oxford University Press, pp. 237-55.

Nelson Laird, Thomas F., Amanda S. Niskode-Dossett, and George D. Kuh. 2009. What general education courses contribute to essential learning outcomes. JGE: The Journal of General Education 58: 65-84. [CrossRef]

Nielsen Arendt, Jacob, Henrik Lindegaard Andersen, and Morten Saaby. 2020. The Relationship between Active Labor Market Programs and Employability of the Long-Term Unemployed. Labour 34: 54-175. [CrossRef]

O'Connell, David J., Eileen McNeely, and Douglas T. Hall. 2008. Unpacking personal adaptability at work. Journal of Leadership and Organizational Studies 14: 248-59. [CrossRef]

Öncel, Levent. 2014. Career Adapt-Abilities Scale: Convergent validity of subscale scores. Journal of Vocational Behavior 85: 13-17. [CrossRef]

Özkurt, Burhan, and Alpay C. Berkan. 2018. Investigation of Proactive Personality Characteristics of the Students of High School of Physical Education and Sports through Various Variables. Asian Journal of Education and Training 4: 150-55. [CrossRef]

Parker, Polly. 2008. Promoting employability in a "flat" world. Journal of Employment Counseling 45: 2-13. [CrossRef]

Parker, Sharon K., Helen M. Williams, and Nick Turner. 2006. Modeling the antecedents of proactive behavior at work. Journal of Applied Psychology 91: 636-52. [CrossRef]

Patton, Wendy, and Jan Lokan. 2001. Perspectives on Donald Super's construct of career maturity. International Journal of Educational and Vocational Guidance 1: 31-48. [CrossRef] 
Patton, Wendy, Dee A. Bartrum, and Peter A. Creed. 2004. Gender differences for optimism, self esteem, expectations and goals in predicting career planning and exploration in adolescents. International Journal for Educational and Vocational Guidance 4: 193-209. [CrossRef]

Pringle, Judith, and Mary Mallon. 2003. Challenges for the boundaryless career odyssey. International Journal of Human Resource Management 14: 839-53. [CrossRef]

Prinsley, Roslyn Tamara, and Krisztian Baranyai. 2015. STEM Skills in the Workforce: What Do Employers Want? Occasional Paper Series; Canberra, Australia: Office of the Chief Scientist No. 9, pp. 1-4.

Pryor, Robert G. L., Norman E. Amundson, and Jim E. H. Bright. 2008. Probabilities and possibilities: The strategic counseling implications of the chaos theory of careers. Career Development Quarterly 56: 309-18. [CrossRef]

R Core Team. 2021. R: A Language and Environment for Statistical Computing. Available online: https://www.r-project.org/ (accessed on 8 August 2021).

Rayner, Gerry M., and Theo Papakonstantinou. 2015. Employer perspectives of the current and future value of STEM graduate skills and attributes: An Australian study. Journal of Teaching and Learning for Graduate Employability 6: 110-25. [CrossRef]

Rayner, Gerry M., and Theo Papakonstantinou. 2016. The nexus between STEM qualifications and graduate employability: Employers' perspectives. International Journal of Innovation in Science and Mathematics Education 24: 3.

Rodrigues, Ricardo. A., and David Guest. 2010. Have careers become boundaryless? Human Relations 63: 1157-75. [CrossRef]

Rosseel, Y. 2017. Package 'Lavaan'. Available online: https:/ / cran.r-project.org/web/packages/lavaan/lavaan.pdf (accessed on 27 June 2021).

Rottinghaus, Patrick J., Kristine L. Buelow, Anna Matyja, and Madalyn R. Schneider. 2012. The career futures inventory-revised: Measuring dimensions of career adaptability. Journal of Career Assessment 20: 123-39. [CrossRef]

Rottinghaus, Patrick J., Susan X. Day, and Fred. H. Borgen. 2005. The Career Futures Inventory: A measure of career-related adaptability and optimism. Journal of Career Assessment 13: 3-24. [CrossRef]

Rudolph, Cort W., Kristi N. Lavigne, and Hannes Zacher. 2017. Career adaptability: A meta-analysis of relationships with measures of adaptivity, adapting responses, and adaptation results. Journal of Vocational Behavior 98: 17-34. [CrossRef]

Ryff, Carol D., and Burton H. Singer. 2008. Know thyself and become what you are: A eudaimonic approach to psychological well-being. Journal of Happiness Studies 9: 13-39. [CrossRef]

Savickas, Mark L., and Erik J. Porfeli. 2012. Career Adapt-Abilities Scale: Construction, reliability, and measurement equivalence across 13 countries. Journal of Vocational Behavior 80: 661-73. [CrossRef]

Savickas, Mark. L. 2013. Career construction theory and practice. Career Development and Counseling: Putting Theory and Research to Work 2: 144-80.

Schermelleh-Engel, Karin, Helfried Moosbrugger, and Hans Müller. 2003. Evaluating the fit of structural equation models: Tests of significance and descriptive goodness-of-fit measures. Methods of Psychological Research Online 8: 23-74.

Segers, Jesse, Ilke Inceoglu, Daniël Vloeberghs, Dave Bartram, and Erik Henderickx. 2008. Protean and boundaryless careers: A study on potential motivators. Journal of Vocational Behavior 73: 212-30. [CrossRef]

Seibert, Scott E., J. Michael Crant, and Maria L. Kraimer. 1999. Proactive personality and career success. Journal of Applied Psychology 84: 416-27. [CrossRef]

Seibert, Scott E., Maria L. Kraimer, and J. Michael Crant. 2001. What do proactive people do? A longitudinal model linking proactive personality and career success. Personnel Psychology 54: 845-74. [CrossRef]

Shaffer, Leigh S., and Jacqueline M. Zalewski. 2011. Career advising in a VUCA environment. NACADA Journal 31: 64-74. [CrossRef]

Shang, Jiayin, and Yiqun Gan. 2009. Analysis of the effects of the proactive personality on graduates' career decision making self-efficacy. Acta Scientiarum Naturalium Universitatis Pekinensis 45: 548-54.

Soresi, Salvatore, Laura Nota, and Lea Ferrari. 2012. Career Adapt-Abilities Scale-Italian Form: Psychometric properties and relationships to breadth of interests, quality of life, and perceived barriers. Journal of Vocational Behavior 80: 705-11. [CrossRef]

Spitzmuller, Matthias, Hock-Peng Sin, Michael Howe, and Shereen Fatimah. 2015. Investigating the Uniqueness and Usefulness of Proactive Personality in Organizational Research: A Meta-Analytic Review. Human Performance 28: 351-79. [CrossRef]

Spurk, Daniel, Judith Volmer, Tamara Hagmaier, and Simone Kauffeld. 2013. Why are proactive people more successful in their careers? The role of career adaptability in explaining multiple career success criteria. In Personality Traits: Causes, Conceptualizations, and Consequences. Edited by Elisabeth E. Crossman and Maria A. Weiler. New York: Nova Publishers.

Spurk, Daniel, Simone Kauffeld, Annika L. Meinecke, and Katharina Ebner. 2016. Why do adaptable people feel less insecure? Indirect effects of career adaptability on job and career insecurity via two types of perceived marketability. Journal of Career Assessment 24: 289-306. [CrossRef]

Stauffer, Sarah D., Marc Abessolo, Gregory Zecca, and Jérôme Rossier. 2019. French-Language Translation and Validation of the Protean and Boundaryless Career Attitudes Scales: Relationships to Proactive Personality, Career Adaptability, and Career Satisfaction. Journal of Career Assessment 27: 337-57. [CrossRef]

Steiger, James H. 1990. Structural Model Evaluation and Modification: An Interval Estimation Approach. Multivariate Behavioral Research 25: 173-80. [CrossRef] [PubMed] 
Sullivan, Sherry E., and Michael B. Arthur. 2006. The evolution of the boundaryless career concept: Examining physical and psychological mobility. Journal of Vocational Behavior 69: 19-29. [CrossRef]

Sullivan, Sherry E., and Yehuda Baruch. 2009. Advances in career theory and research: A critical review and agenda for future exploration. Journal of Management 35: 1542-71. [CrossRef]

Super, Donald E., and Edward G. Kansel. 1981. Career development in adulthood: Some theoretical problems and a possible solution. British Journal of Guidance and Counselling 9: 194-201. [CrossRef]

Thomas, Jeffrey P., Daniel S. Whitman, and Chockalingam Viswesvaran. 2010. Employee proactivity in organizations: A comparative meta-analysis of emergent proactive constructs. Journal of Occupational and Organizational Psychology 83: 275-300. [CrossRef]

Thompson, Bruce. 2004. Exploratory and Confirmatory Factor Analysis: Understanding Concepts and Applications. Washington, DC: American Psychological Association, pp. 1-195.

Tien, Hsiu-Lan Shelley, Sieh-Hwa Lin, Pei-Jung Hsieh, and Shuh-Ren Jin. 2014. The career adapt-abilities scale in Macau: Psychometric characteristics and construct validity. Journal of Vocational Behavior 84: 259-65. [CrossRef]

Tolentino, Laramie R., Vesna Sedoglavich, Vinh Nhat Lu, Patrick Raymund James M. Garcia, and Simon Lloyd D. Restubog. 2014. The role of career adaptability in predicting entrepreneurial intentions: A moderated mediation model. Journal of Vocational Behavior 85: 403-12. [CrossRef]

Travis, Justin, and Elizabeth Freeman. 2017. Predicting entrepreneurial intentions: Incremental validity of proactive personality and entrepreneurial self-efficacy as a moderator. Journal of Entrepreneurship Education 20: 45-57.

Trifiletti, Elena, Dora Capozza, Anna Pasin, and Rossella Falvo. 2009. A validation of the proactive personality scale. TPM-Testing, Psychometrics, Methodology in Applied Psychology 16: 77-93.

Truxillo, Donald M., Elizabeth A. McCune, Marilena Bertolino, and Franco Fraccaroli. 2012. Perceptions of older versus younger workers in terms of big five facets, proactive personality, cognitive ability, and job performance. Journal of Applied Social Psychology 42: 2607-39. [CrossRef]

Uy, Marilyn A., Kim-Yin Chan, Sam Yoke Loo, Moon-ho R. Ho, and Oleksandr S. Chernyshenko. 2015. Proactivity, adaptability and boundaryless career attitudes: The mediating role of entrepreneurial alertness. Journal of Vocational Behavior 86: 115-23. [CrossRef]

Valls, Victor, Vicente González-Romá, Ana Hernandez, and Esperanza Rocabert. 2020. Proactive personality and early employment outcomes: The mediating role of career planning and the moderator role of core self-evaluations. Journal of Vocational Behavior 119: 103424. [CrossRef]

Valor-Segura, Immaculada, Ginés Navarro-Carrillo, Natalio Extremera, Luis M. Lozano, Carlos García-Guiu, Maria Isabel RoldánBravo, and Antonia Ruiz-Moreno. 2020. Predicting job satisfaction in military organizations: Unpacking the relationship between emotional intelligence, teamwork communication, and job attitudes in Spanish military cadets. Frontiers in Psychology 11: 1-9. [CrossRef] [PubMed]

Van Vianen, Annelies E. M., Irene E. De Pater, and Paul T. Y. Preenen. 2009. Adaptable careers: Maximizing less and exploring more. The Career Development Quarterly 57: 298-309. [CrossRef]

Verbruggen, Marijke. 2012. Psychological mobility and career success in the 'new' career climate. Journal of Vocational Behavior 81: 289-97. [CrossRef]

Wang, Mo, and Connie R. Wanberg. 2017. 100 years of applied psychology research on individual careers: From career management to retirement. Journal of Applied Psychology 102: 546-63. [CrossRef]

Warr, Peter. 2008. Work values: Some demographic and cultural correlates. Journal of Occupational and Organizational Psychology 81: 751-75. [CrossRef]

Whalen, Donald F., and Mack Shelley. 2010. Academic Success for STEM and NonSTEM Majors. Journal of STEM Education 11: 45-60.

Wheaton, Blair, Bengt Muthen, Duane F. Alwin, and Gene F. Summers. 1977. Assessing reliability and stability in panel models. Sociological Methodology 8: 84-136. [CrossRef]

Wiernik, Brenton M., and Jack W. Kostal. 2019. Protean and boundaryless career orientations: A critical review and meta-analysis. Journal of Counseling Psychology 66: 280-307. [CrossRef] [PubMed]

Wilson, Emerald Corinne A. 2010. Factors that Predict Students' Educational Experience at a Midwestern Research University: A Comparative Study of STEM and non-STEM Majors. Doctoral dissertation, ProQuest Dissertations and Theses. (UMI No. 848634802). Iowa State University, Ames.

$\mathrm{Xu}$, Yonghong Jade. 2012. Career outcomes of STEM and non-STEM college graduates: Persistence in majored-field and influential factors in career choices. Research in Higher Education 54: 349-82. [CrossRef]

Zacher, Hannes. 2014. Individual difference predictors of change in career adaptability over time. Journal of Vocational Behavior 84: 188-98. [CrossRef]

Zacher, Hannes. 2015. Daily manifestations of career adaptability: Relationships with job and career outcomes. Journal of Vocational Behavior 91: 76-86. [CrossRef]

Zhang, Chunyu, Andreas Hirschi, and Xuqun You. 2020. Trajectories of Calling in the Transition from University to Work: A Growth Mixture Analysis. Journal of Career Assessment 29: 98-114. [CrossRef]

Zhang, Qichao, Zhenzhong Ma, Long Ye, Ming Guo, and Shuzhen Liu. 2021. Future Work Self and Employee Creativity: The Mediating Role of Informal Field-Based Learning for High Innovation Performance. Sustainability 13: 1352. [CrossRef] 
Zhao, Shuming, Yan Liu, and Lulu Zhou. 2016. How does a boundaryless mindset enhance expatriate job performance? The mediating role of proactive resource acquisition tactics and the moderating role of behavioural cultural intelligence. The International Journal of Human Resource Management 31: 1333-57. [CrossRef]

Zheng, Fengjiao, Naseer Abbas Khan, and Sabir Hussain. 2020. The COVID 19 pandemic and digital higher education: Exploring the impact of proactive personality on social capital through internet self-efficacy and online interaction quality. Children and Youth Services Review 119: 105694. [CrossRef] 